\title{
Correction to: "Ecology and vegetation types of oak-hornbeam and ravine forests of the Eastern Greater Caucasus, Georgia"
}

\author{
Pavel Novák • Dominik Zukal • Martin Harásek • \\ Pavla Vlčková • Otar Abdaladze • Wolfgang Willner
}

Published online: 1 July 2021

C Institute of Botany, Czech Academy of Sciences 2021

\section{Correction to: Folia Geobot (2020) 55:333-349 \\ https://doi.org/10.1007/s12224-020-09386-0}

Erroneously, the diagnostic species of the alliance Pachyphragmo macrophyllae-Tilion begoniifoliae Zukal all. nova hoc loco (Holotypus: Hedero pastuchovii-Aceretum velutini Zukal in Novák et al. 2020, Folia Geobotanica 55, p. 347) were not explicitly indicated as required by the ICPN (Art. 8). The new alliance has the following diagnostic species: Acer velutinum, Aruncus dioicus, Asplenium scolopendrium, A. trichomanes, Pachyphragma macrophylla, Paris incompleta, Philadelphus coronarius, Polystichum

The online version of the original article can be found at https://doi.org/10.1007/s12224-020-09386-0

P. Novák $(\bowtie) \cdot D$. Zukal · M. Harásek · P. Vlčková Department of Botany and Zoology, Masaryk University,

Kotlářská 2, CZ-611 37 Brno, Czechia

e-mail: pavenow@seznam.cz

\section{O. Abdaladze}

Institute of Ecology, School of Natural Science and Medicine, Ilia State University, K. Cholokashvili Avenue 5, GE-0162 Tbilisi, Georgia

W. Willner

Department of Botany and Biodiversity Research, University of Vienna, Rennweg 14, A-1030 Vienna, Austria aculeatum, P. braunii, Tilia begoniifolia, Ulmus glabra and Valeriana tiliifolia.

Springer wishes to apologize for any inconvenience caused.

Springer Nature

Publisher's Note Springer Nature remains neutral with regard to jurisdictional claims in published maps and institutional affiliations. 